\title{
Internal Quality Audit Administration Information System In Badan Penjaminan Mutu (Case Study: Universitas Lancang Kuning)
}

\author{
Bayu Febriadi \\ Department of Information System, Faculty of Computer Science, Lancang Kuning \\ University \\ Jl. Yos Sudarso KM. 8 Rumbai, Pekanbaru, Riau, telp. 08117532015 \\ bayufebriadi9@gmail.com
}

\begin{abstract}
Lancang Kuning University Mapping and Implementation of the Internal Quality Assurance System (SPMI) was implemented from 2008 with the establishment of the Quality Assurance Agency (BPM) and Quality Assurance Unit (UPM) at the Faculty level with the aim of creating a quality culture in the Lancang Kuning University Academic Community, in the process of implementing the internal quality assurance system at the quality assurance agency, it has also carried out Monitoring and Evaluation (Monev) once a year to guarantee the quality culture that has been implemented, but in the implementation of Monitoring and Evaluation the Quality Assurance Agency always experiences obstacles such as technical, technical and recording data during activities and also in document archiving because there is no media that can be utilized in managing monitoring and evaluation while the application of information technology and resources already exists. With the use of information technology in the application of computerized based applications for filing and presenting data needs, it is expected to help the academics more quickly and precisely in processing data monitoring and evaluation as well as a means of implementing accreditation by the National Accreditation Board of Higher Education (BAN-PT). It is expected that with the development of applications in the management of monitoring and evaluation by completing the System Development Lyfe Cycle (SDLC) method in the problem analysis phase, the application that is built can improve the quality of monitoring and evaluation in data processing that is well integrated and can be utilized at any time by Lancang Kuning University academic community.
\end{abstract}

Keywords: Information System, Accreditation, Lancang Kuning University.

\section{Introduction}

The determination of quality assurance for all universities through the Higher Education Quality Assurance System (SPM Dikti) has long been announced by the government. Under Law No. 12 of 2012 concerning Higher Education, the Dikti SPM includes the Internal Quality Assurance System (SPMI) and the External Quality Assurance System (SPME) or better known as Accreditation [1-4].

At Lancang Kuning University Mapping and Implementation of the Internal Quality Assurance System (SPMI) was implemented from 2008 with the establishment of the Quality Assurance Agency (BPM) and Quality Assurance Unit (UPM) at the Faculty level with the aim of creating a quality culture in the Lancang Kuning University Academic Community, in the process of implementing the internal quality assurance system at the quality assurance agency, it has also carried out Monitoring and Evaluation (Monev) once a year to guarantee the quality culture that has been implemented, but in the implementation of Monitoring and Evaluation the Quality Assurance Agency always experiences obstacles such as technical, 
technical and recording data during activities and also in document archiving because there is no media that can be utilized in managing monitoring and evaluation while the application of information technology and resources already exists. With the use of information technology in the application of computerized based applications for filing and presenting data needs, it is expected to help the academics more quickly and precisely in processing data monitoring and evaluation as well as a means of implementing accreditation by the National Accreditation Board of Higher Education (BAN-PT) [5-7]. It is expected that with the development of applications in the management of monitoring and evaluation by completing the System Development Lyfe Cycle (SDLC) method in the problem analysis phase [8], the application that is built can improve the quality of monitoring and evaluation in data processing that is well integrated and can be utilized at any time by Lancang Kuning University academic community [9-12].

Based on the description above, the writer tries to discuss and put it in a study entitled Internal Academic Quality Audit Administration Information System at the Lancang Kuning University. The formulation of the problem in this article is as follows:

a. How to design an archiving information system as a medium that can be used in the accreditation instrument data requirements at Lancang Kuning University?

b. How can using information technology-based applications provide information more effectively and efficiently in the preparation of accreditation instruments?

\section{Research Methodology}

the research methodology and research framework used in the completion of this study. This framework is the steps to be taken in order to solve the problem which will be discussed. The stages in the modeling used are Waterfall modeling, and can be seen in the picture below :

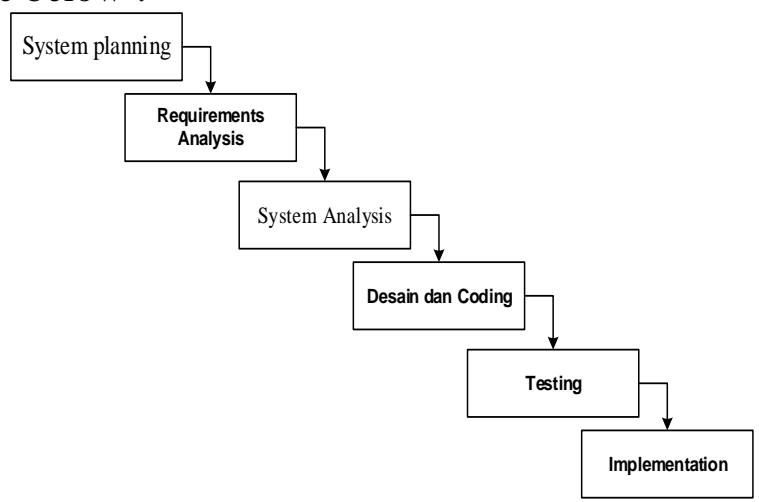

1. System Planning

Figure 1. Waterfal Model Stages

This modeling begins with looking for the needs of the entire system that will be applied in the form of software. This is very important, reminding software to be able to interact with other elements such as hardware, databases, and so on. This stage is often called project definition. System design begins with conducting research on the elements - the elements of the system requirements in question and defining the needs - needs in the implementation of Internal Quality Audit at the Quality Assurance Agency at Lancang Kuning University.

2. Requirements Analysis

The search process needs to be intensified in the software. To find out the nature of the program to be created, the software engineers must understand the domain of information from the software. By collecting data needs by application users in the 
development of filing systems that will be built in this case the developer collects accreditation data with the auditor instrument compilation team in the implementation of monitoring and evaluation of each study program and work units that exist in the Lancang Kuning University.

\section{System Analysis}

System Analysis is the decomposition of an intact system into its component activities, with the intention of identifying and evaluating problems, opportunities, constraints, occurring and expected needs so that improvements can be proposed in the implementation of the audit internal quality at Lancang Kuning university.

\section{Design Systems}

System Design is an implementation design preparation that describes how a system is formed in the form of depiction, planning and making sketches or arrangements of several separate elements into a single unit that is intact and functioning, involving the configuration of software and hardware components of a system.

\section{Coding}

In this case, this is a computer, so the design must be transformed into a form that can be understood by the machine, namely into the programming language through the coding process.

\section{Testing}

Something that is made must be tested and the results must be truly in accordance with the needs that have been previously defined.

7. Implementasi

The implementation stage is the stage where all system elements and activities are combined with the following steps:

a. Preparing Physical Facilities

Physical facilities that are prepared include computers and peripherals, including physical security to keep the equipment going for a long time.

b. Prepare the user

The user is prepared in advance, namely by providing procedural training as well as a tutorial on information systems according to their task functions. The aim is for users to understand and control system operations and how the system works and what is obtained from the system.

c. Perform a simulation

Simulation activities in the form of real system testing involving real personel.

\section{Results and Discussion}

\subsection{The design of the administrative information system for academic internal} quality audits

Designing an internal quality audit administration information system in information technology-based universities using the development method of development lyfe cycle (SDLC) using a unified modeling language (UML) approach system.

\section{a. Usecase Diagram}

Usecase Diagram explains the description of the actors involved in using the accreditation internal audit system to be built, can be seen in the picture below: 
Explanation:

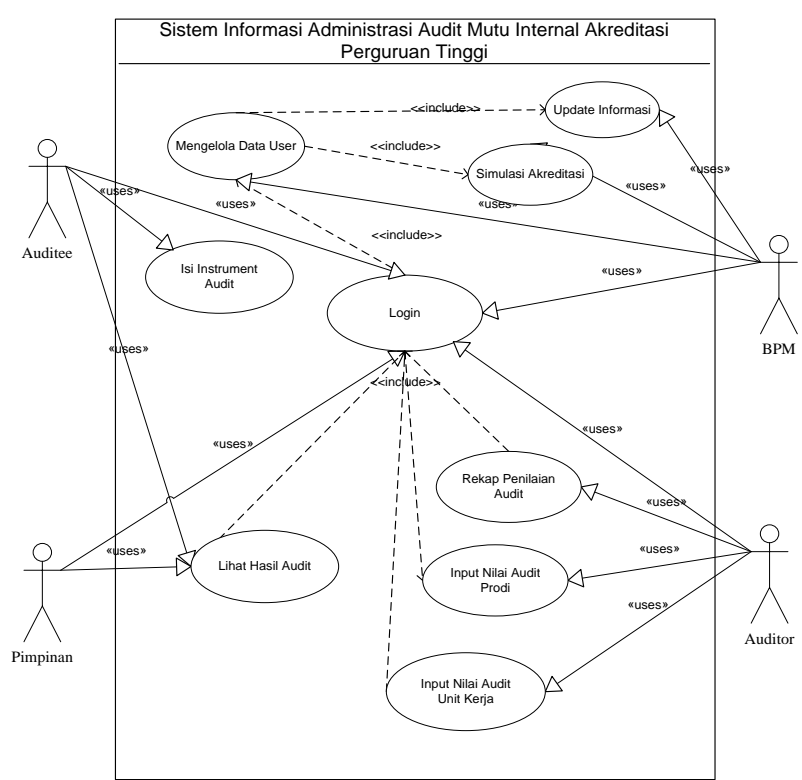

Figure 1. Usecase Diagram

1. In developing the system there are 4 actors, namely: Quality Assurance Agency, Accreditation Team, Dean and Study Program.

2. The Quality Assurance Agency is in charge of controlling the system, filling in the content, managing the system user account, maintenance application information system, internal quality audit, college accreditation instrument.

3. The Auditor Team serves as a team that conducts monitoring and evaluation of the implementation of quality standards that are present in Lancang Kuning University, along with giving an asse ssment

4. The Auditee has the duty to upload instrument form IIIa, selfevaluation, Strategic Plan and Renop of each Study Program.

All actors must log in first before carrying out activities in the system.

\section{b. Activity Diagram}

Activity Diagram explains how the flow of the system developed in the international onference participant register is based online, can be seen in the picture below in:

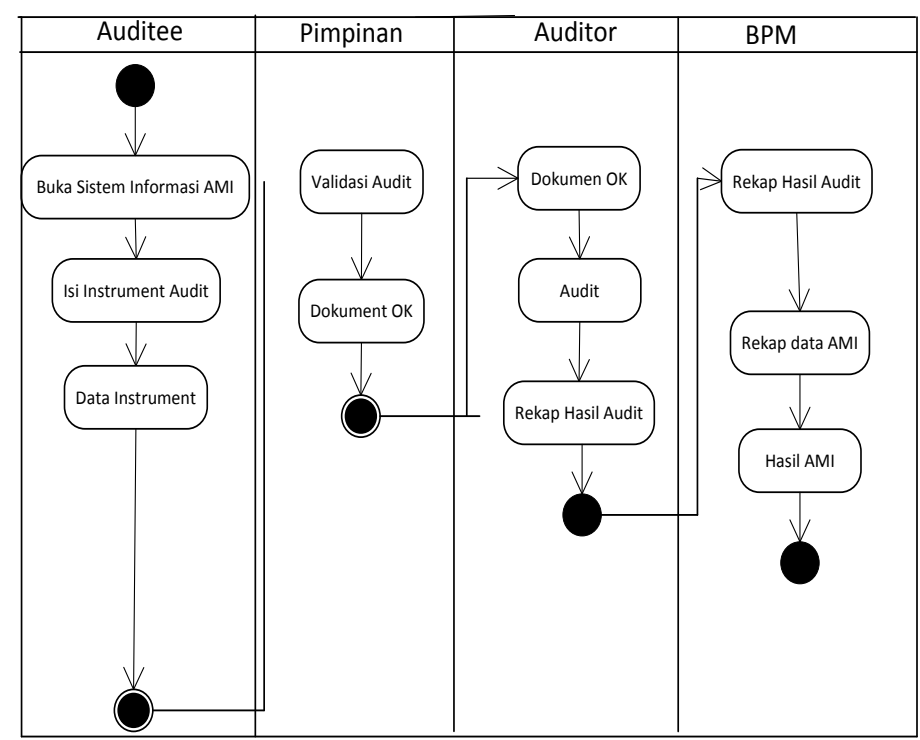

Figure 2. Activity Diagram 
Explanation:

a. In the activity diagram explain each actor in the internal quality audit information system for accreditation of the yellow sassy university system based online.

b. BPM also reads and sees guidelines in viewing accreditation instruments that have been uploaded by the study program and the dean and accreditation team then conducts simulations in accreditation to provide the value of accreditation for study programs.

c. The Auditor Team uploads standard data on college performance reports and self-evaluation reports and university strategic plans and plans.

d. Auditee uploads study program forms and strategic plans to the university accreditation internal quality audit information system.

\section{c. Class Diagram}

Class Diagram explains the entities and attributes in the Information system The internal quality audit system for accreditation instruments can be seen in the picture below:

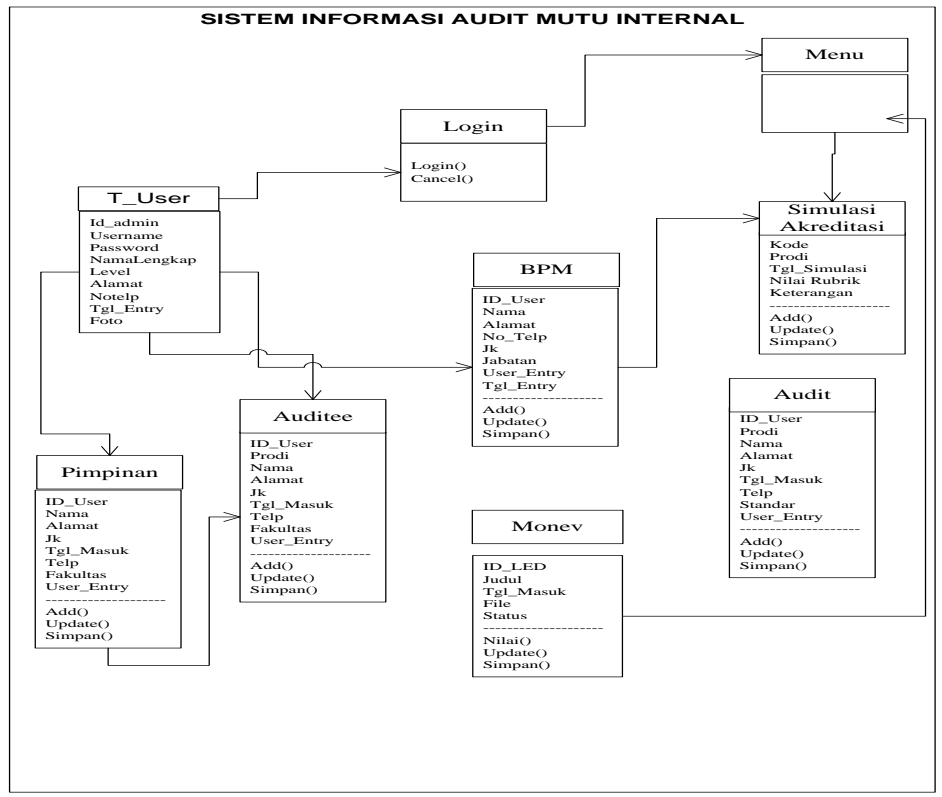

Figure 3. Class Diagram

Explanation:

In class diagram there are 4 entities in the Information system of the accreditation internal audit system: Login, Fill in the Audit Instrument, Audit, Auditee, Auditor, Leader, BPM, Study Program and Dean.

a. Each entity has an attribute which is an explanation of the entity.

b. In the class diagram also describes the integrity of the data flow in the system being developed.

\subsection{New system interface}

In the new system view that has been built based on the previous design of usecase diagrams, activity diagrams, and class diagrams. From the explanation of the Unified Modeling Language.

\section{a. Main Menu}

In the design of the system that was built the main menu is the Academic Internal Quality Audit System Information System accreditation at Lancang Kuning University in the picture below. 


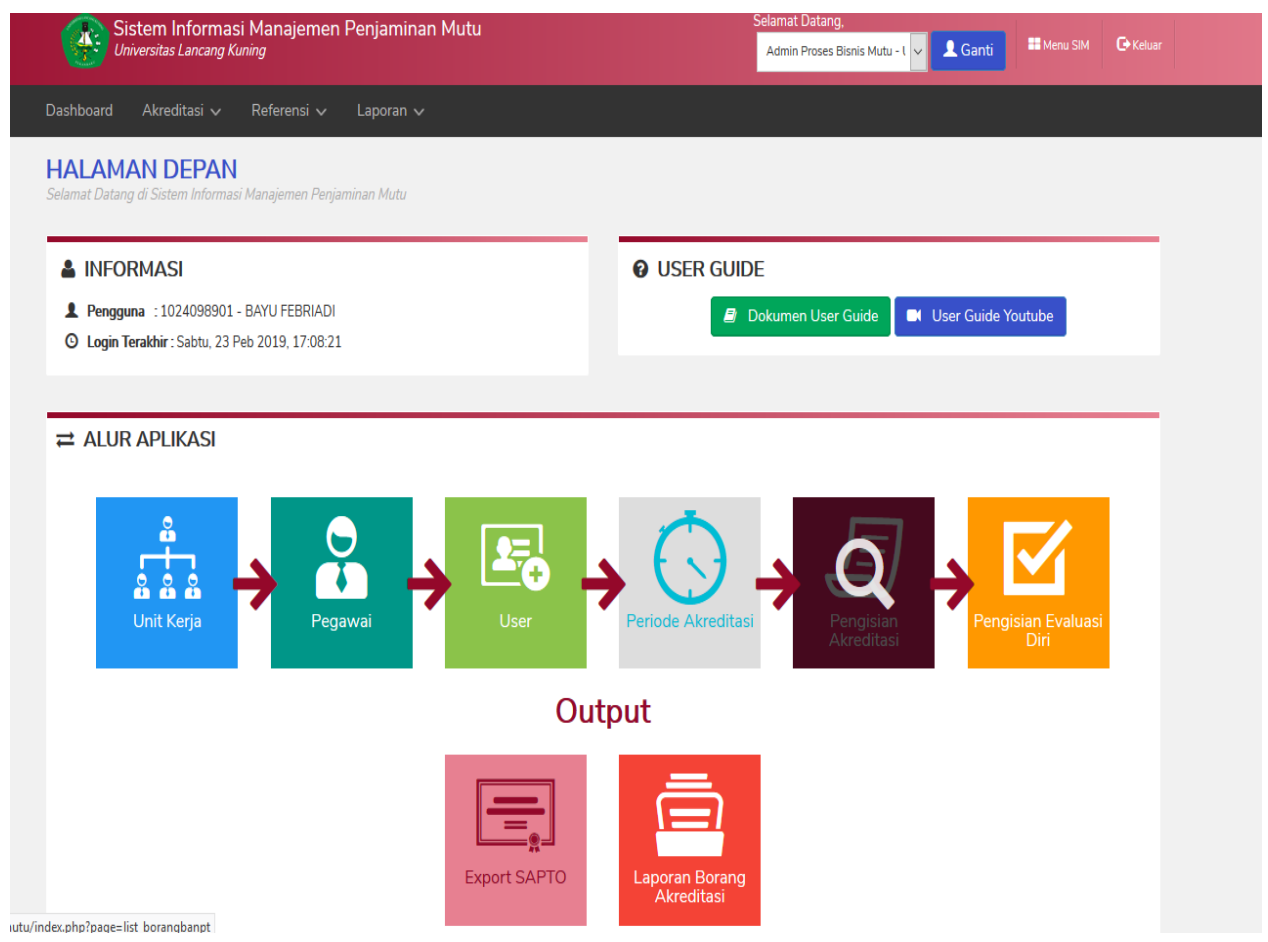

Figure 4. Display of the Main Menu

\section{b. Auditor Valuation}

In the design of the system built the main menu of the internal quality audit system Information System where the auditor assesses the audit data that has been filled in by the auditee at Lancang Kuning University in the picture below.

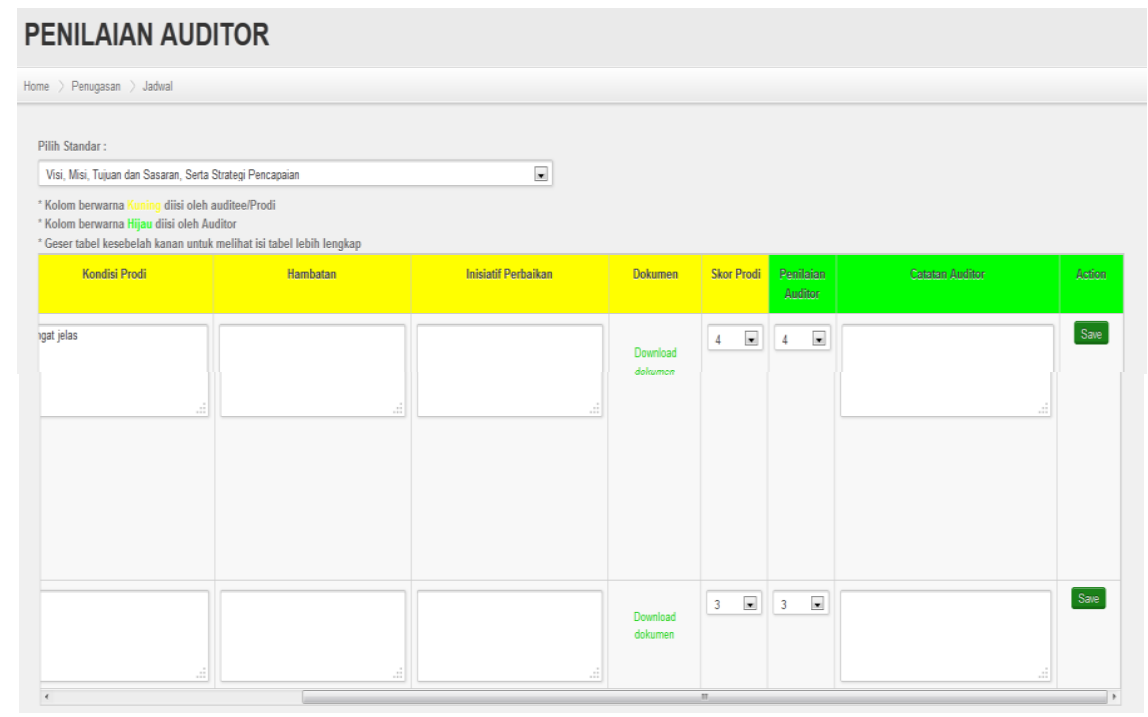

Figure 5. Auditor Valuation

\section{c. List of Auditee Fields}

In the design of the system that was built the auditee information system internal quality audit system to fill in the accreditation period at Lancang Kuning University in the picture below. 


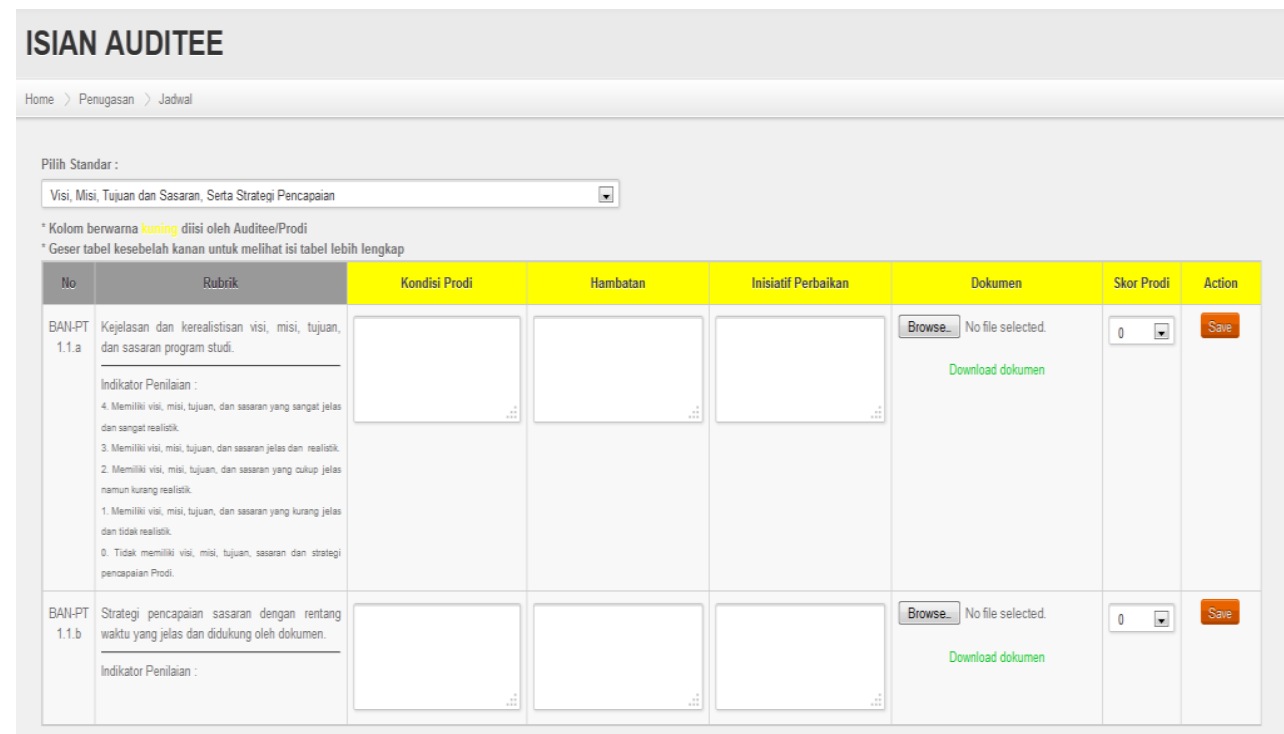

Figure 6. List of Auditee Fields

\section{Conclusion}

After conducting research activities at the yellow sassy university, the authors conclude that:

a. Information System Application internal quality audit of accreditation instrument that has been built as a media in accreditation activities so that the accreditation instrument data is better integrated with Lancang Kuning University.

b. By utilizing data-based applications so that data processing of monitoring activities and evaluation of academic internal quality audits can be done quickly and precisely by the Lancang Kuning University academic community.

\section{References}

[1] Fathansyah, "Sistem Basis Data. Bandung: Informatika", (2004).

[2] Febriadi, Bayu. 2017. "Efisiensi Sistem Informasi berbasis Online Dalam pengumpulan RPKPS mata Kuliah Untuk Pengembangan Kompeteensi Program Studi" Vol 8, No. 1, Digital Zone, “Jurnal teknologi Informasio dan Komunikasi".

[3] Kadir, Abdul. 2005. Pengenalan Sistem Informasi. Jakarta, Yogyakarta: Andi

[4] Herawati, Y., "Rekayasa Perangkat Lunak Untuk Penjualan Perlengkapan Pengantin Adat Minangkabau Berbasis Web", Padang: Institut Teknologi Padang, (2013).

[5] Isa, I., "Sistem Informasi", Jakarta: Graha Ilmu, (2012).

[6] Mohammad Yazdi, 2012, e-learning sebagai media pembelajaran interaktif berbasis teknologi informasi, urnal Ilmiah Foristek Vol. 2, No. 1, Maret 2012, Fakultas Matematika dan Ilmu Pengetahuan Alam, Universitas Tadulako.

[7] Nyimas Sriwihajriyah, 2012, Perancangan aplikasi E-Profile berbasis online sebagai sarana informasi dosen pada stmik pusri Palembang, Jurnal Sistem Informasi (JSI), VOL. 4, NO. 1, April 2012.

[8] Nugroho, A., "Rekayasa Perangkat Lunak Berorientasi Objek dengan Metode USDP”, Andi, (2010).

[9] Oneto, Erima. 2008. Cascadading Management Style Sebagai media Program Berbasis Web. Bandung: Informatika 
[10] Saraswati, E., "Sistem Informasi Akademik Berbasis Web Pada Sekolah Menengah Pertama Negeri 3 Pringkuku", Indonesian Journal On Networking and Security - IJNS, (Volume 2 No 4 - Oktober 2013, ISSN: 2302-5700).

[11] Simarmata, J, “Rekayasa Perangkat Lunak”, Andi, (2010).

[12] Sutabri, Tata. 2005. Sistem Informasi Managemen. Jakarta: Andi Jogjya

\section{Authors}

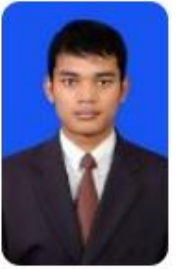

$\mathbf{1}^{\text {st }}$ Author

Bayu Febriadi

Department of Information System

Faculty of Computer Science,

Lancang Kuning University 